\title{
The pattern of Etlingera elatior cultivation in agroforestry systems and its use as traditional medicines and food by local people of Kabanjahe, North Sumatra, Indonesia
}

\author{
AGUS PURWOKO ${ }^{1}$, HELTIMALA TURNIP ${ }^{1}$, WAHYU HARYATI MASER ${ }^{2, \boldsymbol{}}$ \\ ${ }^{1}$ Department of Forest Management, Faculty of Forestry, Universitas Sumatera Utara. Jl. Tridarma Ujung No. 1, Medan 20155, North Sumatra, Indonesia \\ ${ }^{2}$ Program of Food Science and Technology, Faculty of Agriculture, Universitas Sumatera Utara. Jl. Prof. A. Sofyan No 3 Kampus USU, Medan 20155, \\ North Sumatra, Indonesia. Tel.: +62-61-8213236, Fax.: +62-61-8211924,"email: maser.wahyuharyati@usu.ac.id
}

Manuscript received: 30 May 2019. Revision accepted: 28 June 2019.

\begin{abstract}
Purwoko A, Turnip H, Maser WH. 2019. The pattern of Etlingera elatior cultivation in agroforestry systems and its use as traditional medicines and food by local people of Kabanjahe, North Sumatra, Indonesia. Biodiversitas 20: 1998-2003. Etlingera elatior or kecombrang (Indonesian name) is a native plant of Indonesia. In Kabanjahe, this plant is planted in agroforestry systems. The purposes of this study were to describe the pattern of Etlingera elatior cultivation in agroforestry systems, and to document the use of Etlingera elatior as medicines and food by the local people of Kabanjahe, North Sumatra. Data were collected with field observations and interviews, and the collected data were analyzed qualitatively. The results showed that kecombrang was planted in agroforestry systems in three patterns, namely (i) kecombrang, cinnamon, and coffee, (ii) kecombrang, coffee, and bamboo, and (iii) and kecombrang, avocado, and vegetables. Kecombrang has been used as medicines for cough, wound, eye problems, fever, low breast milk production, odor, and hair thinning. In addition, kecombrang has also been used as a food ingredient in ubi tumbuk, ikan arsik, sambal kincung, getah tasak telu, cipera, terong dotak, gat-gat, and gulen manuk. With this research, it is suggested that agroforestry systems be developed to improve economic benefits for the local people of Kabanjahe.
\end{abstract}

Keywords: Etlingera elatior, food, Kabanjahe, kecombrang, local people, medicines

\section{INTRODUCTION}

One of the problems in the forestry sector is the low economic productivity of land which often results in the conversion of forest land into other non-forestry uses. On the other hand, the development of the agricultural sector is constrained by the limited land owned by farmers, so the majority of farmers practice farming below the good economic scale. These two problems can be overcome with agroforestry system, which is a land use system that combines forest with agricultural crops to increase benefits, both economically and environmentally (Ruijter and Agus 2004).

As a mixed farming model, the concept of agroforestry is required to grow species, both main crops (forestry) and their combination plants (agriculture) that are able to offer high productivity and economic benefits. This starts with the selection of tolerant species when planted together with forestry crops, the economic benefits of the commodities produced, and the prospects for their use and market. Modern agroforestry is now based mainly on the combination of trees plantation infield which can be grown along with agricultural, vegetable crops species, horticultural crop species, animals' species, poultries, fisheries, etc or produced simultaneously or subsequently in combined models on the same piece of land (Himshikha 2016). Many species of agricultural crops can be planted in agroforestry systems, especially plants that are relatively tolerant to both light cover and low soil nutrient availability. One of Indonesia's local plants suitable to grow in agroforestry systems is kecombrang (Etlingera elatior (Jack) R. M. Sm). In addition, this plant species has provided many benefits for the community, especially as medicinal plants. The parts of the plant used are the pseudostems, leaves, fruit, and rhizomes (Sabilu et al. 2017). Etlingera elatior is native to Malaysia and Indonesia, belonging to the family Zingiberaceae (Chan et al. 2011). Yeats (2015) states that kecombrang generally grows in lowland wet tropics and can be found at altitudes up to $2700 \mathrm{~m}$. Research conducted by Delta et al. (2013) also stated that the spread of kecombrang on Mount Talang ranged from 1169-1258 m. The plants of family Zingiberaceae family usually grow in colonies or clumps with very large stature such as kecombrang. Some kecombrang have adventitious roots that grow laterally and below the rhizome. Its rhizome is commonly called a rounded rhizome like taro, soft and fleshy (Delta et al. 2013). Having strong and creeping roots kecombrang is often found in steep soils (Yeats 2015). E. elatior grows up to 5-6 m tall forming clumps (Khaw 2011). Its aromatic rhizomes are stout (3-4 cm in diameter) and found just below the ground level. When crushed, the leaves emit a pleasant sour fragrance. The leaves are entirely green with a truncated base. Young leaves are sometimes flushed pink with petioles $2.5-3.5 \mathrm{~cm}$ in length. Inflorescences, which are shaped like a spear-head when young, are large and attractive with showy pink or red waxy bracts when in blossom. Fruiting heads are globular, greenish or red in color, bearing many black seeds (Chan et al. 2013). 
Kecombrang's flowers and young leaves are generally used as a flavoring for dishes, such as urab, pecel, sambal, and other dishes. Young inflorescences are an essential ingredient of sour curry dishes (Larsen et al. 1999). For the people of North Sumatra, kecombrang's flowers are used as a mixture of sambal lalap and ubi tumbuk. Besides being widely known as a food ingredient, this plant is also widely known as a medicinal plant. Kecombrang's flower has also been widely used by the community for medicinal purposes because of the active substances contained in them such as tannins, flavonoids, saponin, and steroid (Maimulyanti and Prihadi 2015).

Most of the local people in Kabanjahe Sub-Districts are farmers who practice agroforestry, growing several species of plants, such as cinnamon, coffee, bamboo, avocado, and kecombrang. However, there had been no study about kecombrang cultivation in the agroforestry systems and its use as medicines and food. Therefore, this study was conducted to describe the pattern of kecombrang cultivation in agroforestry systems and to document the use of kecombrang as medicines and food in Kabanjahe Subdistrict.

\section{MATERIALS AND METHODS}

\section{Study area}

The study was conducted in Kabanjahe Sub-district, Karo District, North Sumatra, Indonesia. The location is flanked by 3 Sub-districts, namely, north with Berastagi Sub-district, south with Tigapanah Sub-district, west with Simpang Empat Sub-district, and east with Tigapanah Subdistrict (Figure 1). Kabanjahe Sub-district is at altitudes of $1000-1300 \mathrm{~m}$ with a temperature of $16-27^{\circ} \mathrm{C}$ and an area of $44.65 \mathrm{~km}^{2}$. Kabanjahe Sub-district covers 13 villages, with a population of 73,479 inhabitants (BPS 2017).

\section{Procedures}

Data were collected with field observations (surveys) and interviews. The surveys were done in 25 samples of agroforestry systems and structured interviews were done with the owners. The samples were selected purposively based on the research objectives. The purposive sampling technique is a type of non-probability sampling that is most effective when one needs to study a certain cultural domain with knowledgeable experts within. Informant selection is highly relevant for ethnobotanical research, as people are constantly looked upon for knowledge and information. (Tongco 2007).

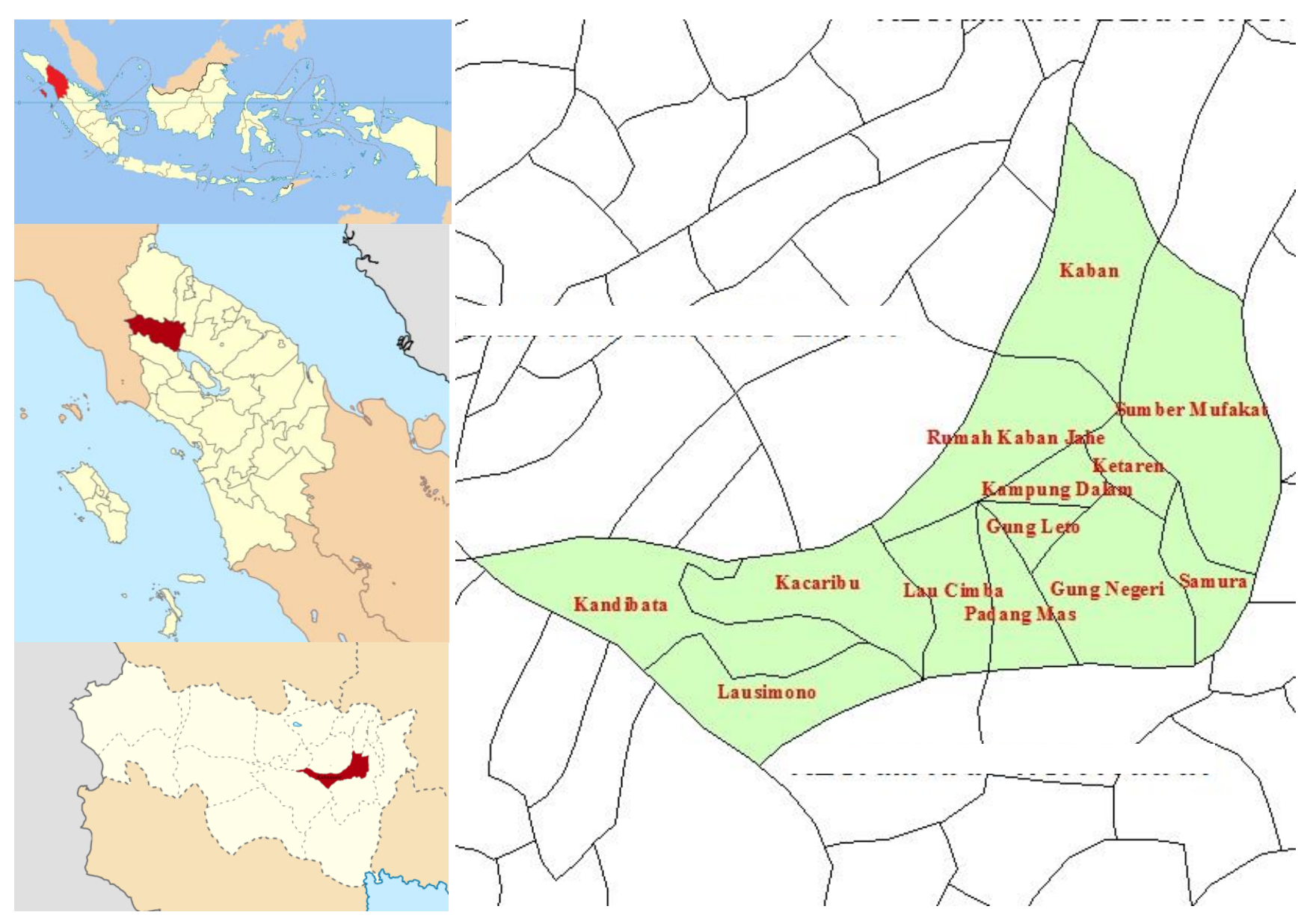

Figure 1. The location of research, Kabanjahe Subdistrict, Karo District, North Sumatra, Indonesia 
Structured interviews were carried out using questionnaires that had been prepared and filled out by researchers while conducting interviews with respondents. The observation was done by observations up close, note taking and documentation in the form of photographs.

\section{Data analysis}

The data were analyzed qualitatively. Qualitative data analysis is the process of classical basic methods of research such as data collection, documentation, analysis, and interpretation (Akinyode and Khan 2018). The process runs through research design, fieldwork, and analysis (Braun and Clarke 2006; Attride-Stirling 2001).

\section{RESULTS AND DISCUSSION}

\section{Characteristics of respondents}

Respondents in Kabanjahe Subdistrict adhere to various religions, namely Islam, Protestant, and Catholicism and belong to several tribes, namely Javanese, Simalungun Batak, Toba Batak, and Karo Batak. Based on Table 1, it can be seen that the highest percentage of respondents who used kecombrang were 41-49 years old (28\%), high school graduates $(64 \%)$, and having $400 \mathrm{~m}^{2}-6800 \mathrm{~m}^{2}$ agroforestry land $(84 \%)$. Respondents who used a lot of kecombrang came from relatively old age groups because younger people are less interested in local knowledge about medicinal plants and food (Voeks 2007; Guimbo et al. 2011). The area of land used by the community for kecombrang agroforestry was mostly not extensive, but the land will produce good crops, because of the planting is more intensive, decreases overall land use (Assunção et al. 2016).

Respondents had used parts of kecombrang as food and medicine (Figure 2), and the most commonly used part was the stem (17 respondents). The stem was used for various kinds of medicines to cure health problems such as cough, eye, fever, hair thinning and it was also used as ingredient of foods such as ikan arsik and terong dotak. In addition, the essential oils from the stem can also be used for medicine and food (Jaafar et al. 2007; Abdelwahab et al. 2010).

\section{The patterns of kecombrang cultivation in agroforestry systems}

There were three crop patterns in agroforestry systems where kecombrang was planted, namely (i) kecombrang, cinnamon, and coffee, (ii) kecombrang, coffee, and bamboo, and (iii) kecombrang, avocado, and vegetables (Figure 3). Communities in Kabanjahe Sub-district planted kecombrang in the middle of the land. This was intended to get shade from other plants planted. In general, wellmanaged agroforestry systems have positive effects on soil fertility compared with monocultures because of the contributions of trees. Tree plantation-crop combinations, in which (for example) tea, coffee or cocoa are cultivated under trees, and home gardens, in which a high diversity of tree and crop species is grown on the same piece of land, are examples of agroforestry systems that exhibit higher soil fertility than monocultures of the same crops (Hillbrand et al. 2017). Because of tree shade in agroforestry systems, not all species of plants can be planted with trees. Therefore, the choice of plants that are tolerant to shade in agroforestry systems is necessary. Farmers planted forestry and agricultural crops (agrosilvicultural) and the dominant forestry plant was cinnamon (Cinnamomum verum). Other crops were coffee, bamboo, avocado, and vegetables.

Figure 4 shows that $52 \%$ of respondents planted kecombrang, cinnamon, and coffee in their agroforestry land because the income obtained with this pattern was greater than with other patterns. The yield of cinnamon and coffee had high economic value. The bark of cinnamon is widely used as a spice and flavoring material. Moreover, it is used in the preparation of chocolate, desserts recipes (apple pie, doughnuts, and cinnamon buns), spicy candies, tea, hot cocoa and liqueurs (especially in Mexico, the main importer of true cinnamon) (Bandara et al. 2011). Furthermore, coffee is a beverage that is often consumed by the public. In addition, coffee is also used as a mainstay commodity in the plantation sector. Many people process coffee to make beverage and foods that are of high quality and have a selling price (Fujioka and Shibamoto 2008).

\section{Kecombrang for medicines}

Table 2 shows that kecombrang has been used as a medicine for cough, wound, eye, and fever, and to improve breast milk production, remove odor, and fertilize hair. Several studies have shown that kecombrang's flowers had antibacterial activity (Maser et al. 2017; Ghasemzadeh et al. 2015; Wijekoon et al. 2013; Abdelwahab et al. 2010; Lachumy et al. 2010). Kecombrang contains bioactive compounds such as polyphenols, alkaloids, flavonoids, steroids, saponins and essential oils which are thought to have potential as antioxidants and also alternative natural preservatives (Wijekoon et al. 2011). Table 3 shows several studies on the bioactivity of kecombrang which indicate that kecombrang has the potential to be used as medicine.

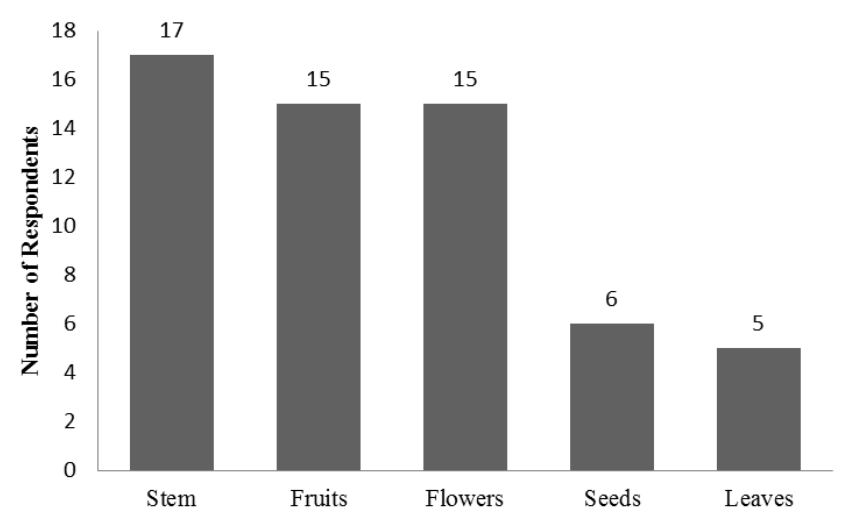

Figure 2. Parts of plants used as foods and medicines by local people Kabanjahe, North Sumatra, Indonesia 
Table 1. The Characteristics of respondents based on age, level of education, and kecombrang agroforestry land area.

\begin{tabular}{cccccc}
\hline & \multicolumn{5}{c}{ Characters of respondents } \\
\hline $\begin{array}{c}\text { Interval of age } \\
\text { (years) }\end{array}$ & $\begin{array}{c}\text { Percentage of } \\
\text { respondents }(\boldsymbol{\%})\end{array}$ & $\begin{array}{c}\text { Level of } \\
\text { education }\end{array}$ & $\begin{array}{c}\text { Percentage of } \\
\text { respondents }(\boldsymbol{\%})\end{array}$ & $\begin{array}{c}\text { Interval of land } \\
\text { area }\left(\mathbf{m}^{\mathbf{2}}\right)\end{array}$ & $\begin{array}{c}\text { Percentage of } \\
\text { respondents }(\%)\end{array}$ \\
\hline $23-31$ & 8 & Elementary School & 8 & $400-6800$ & 84 \\
$32-40$ & 24 & Middle School & 16 & $7200-13600$ & 12 \\
$41-49$ & 28 & High School & 64 & 214000 & 4 \\
$50-58$ & 20 & College & 12 & & \\
$59-67$ & 12 & & & & \\
$68-76$ & 8 & & & & \\
\hline
\end{tabular}
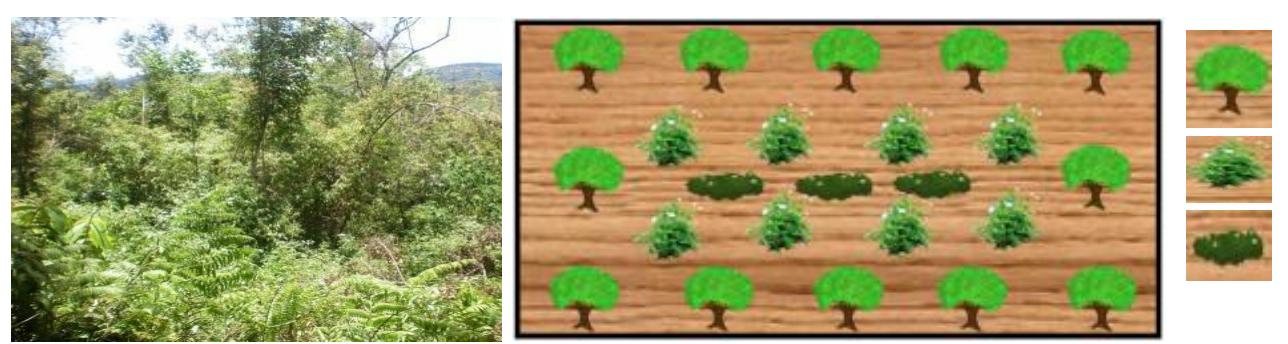

Cinnamon

Coffee

Kecombrang

Pattern of kecombrang, cinnamon, and coffee
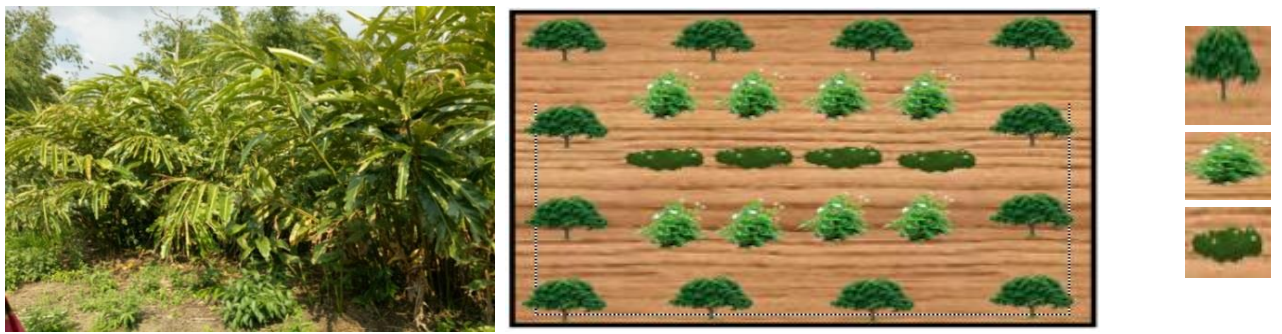

Bamboo

Coffee

Kecombrang

Pattern of kecombrang, coffee, and bamboo
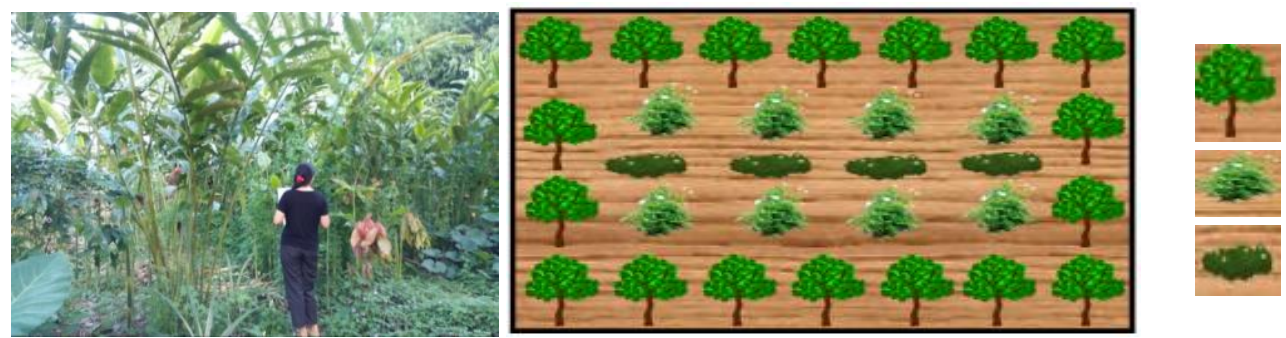

Avocado

Vegetables

Kecombrang

Pattern of kecombrang, avocado, and vegetables

Figure 3. The patterns of crop cultivation in agroforestry systems by local people of Kabanjahe, North Sumatra, Indonesia

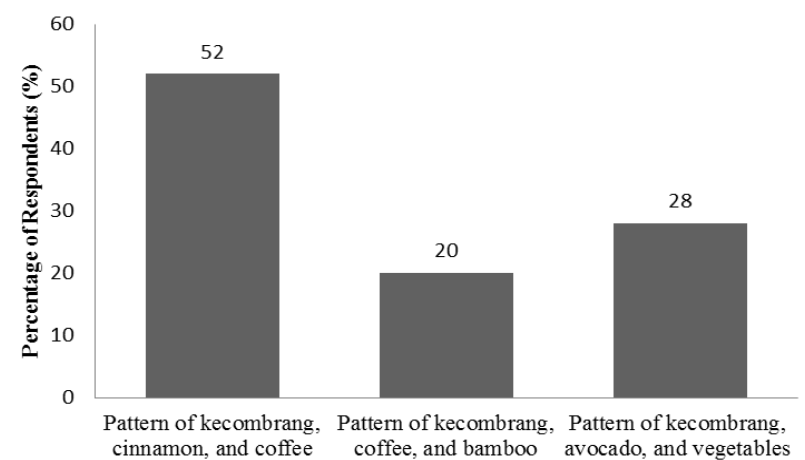

Figure 4. Percentage of respondents (\%) using each agroforestry patterns

\section{Kecombrang for foods}

Kecombrang was used as a food ingredient in $u b i$ tumbuk, arsik, sambal kincung, getah tasak telu, cipera, terong dotak, gat-gat, and gulen manuk (Table 2). Kecombrang has good nutrition, so very suitable to be processed as food. The kecombrang had a significant amount of crude protein (12.6\%), fat (18.2\%), fiber content $(17.6 \%)$, high level of unsaturated fatty acids (palmitoleic acid $16.4 \%$, linoleic acid $14.5 \%$, and oleic acid $5.2 \%$ ), essential amino acids dominated by leucine and lysine (7.2 and $7.9 \mathrm{mg} / 100 \mathrm{mg}$ protein, respectively), and major minerals like: K (1589 mg/100 g), Ca (775 mg/100g), Mg $(327 \mathrm{mg} / 100 \mathrm{~g}), \mathrm{P}(286 \mathrm{mg} / 10 \mathrm{0g})$ and $\mathrm{S}(167 \mathrm{mg} / 100 \mathrm{~g})$ (Wijekoon et al. 2011). 
Table 2. List of kecombrang utilization as medicine and food by local people Kabanjahe, North Sumatra, Indonesia

\begin{tabular}{|c|c|c|c|c|}
\hline $\begin{array}{c}\text { Parts of } \\
\text { kecombrang }\end{array}$ & $\begin{array}{l}\text { Utilization } \\
\text { Types }\end{array}$ & Purposes of use & Specifications & Processing \\
\hline \multirow[t]{6}{*}{ Stem } & Medicine & Cough & $\begin{array}{l}30-40 \mathrm{~cm} \text { long, young } \\
\text { shoots, } 4 \text { months old } \\
\text { with } \pm 2 \text { leaves. }\end{array}$ & $\begin{array}{l}\text { The stem was burned then pounded and squeezed to get the } \\
\text { water. Then the water was drunk }\end{array}$ \\
\hline & & Eye & 8 months old. & $\begin{array}{l}\text { The stem was pounded and squeezed to produce water then the } \\
\text { juice was filtered. The water was used as eye drops. }\end{array}$ \\
\hline & & Fever & $\begin{array}{l}\text { young shoots, } 4 \text { months } \\
\text { old. }\end{array}$ & $\begin{array}{l}\text { The stem was cut and the young shoots were peeled, then } \\
\text { pounded to produce water. The water was placed on the wool } \\
\text { material to be attached to the body that feverish. }\end{array}$ \\
\hline & & Thinning hair & $\begin{array}{l}30-50 \mathrm{~cm} \text { long, } 8 \text { months } \\
\text { old. }\end{array}$ & $\begin{array}{l}\text { The stem was cut and the young shoots were peeled then } \\
\text { pounded to produce water. The water was used as a shampoo. }\end{array}$ \\
\hline & Food & Ikan arsik & $30 \mathrm{~cm}$ long, 1-year-old. & $\begin{array}{l}\text { The stem was sliced into small pieces and mixed into ikan } \\
\text { arsik. }\end{array}$ \\
\hline & & Terong dotak & $30 \mathrm{~cm}$ long, 1-year-old. & The stem was sliced into small pieces and mixed into terong dotak \\
\hline \multirow[t]{2}{*}{ Fruit } & Food & Cipera & - & The fruit was sliced into small pieces and mixed into cipera. \\
\hline & & Terong dotak & - & The fruit was finely ground and mixed into terong dotak. \\
\hline \multirow[t]{6}{*}{ Flower } & Medicine & $\begin{array}{l}\text { Improve } \\
\text { breastmilk } \\
\text { production }\end{array}$ & $\begin{array}{l}\text { young, } 4 \text { months old, } \\
\text { having shoots, blooming. }\end{array}$ & The flowers were thinly sliced and mixed into the food. \\
\hline & & Remove odor & $\begin{array}{l}\text { young, } 4 \text { months old, } \\
\text { blooming. }\end{array}$ & The flowers were boiled with water and used for bathing. \\
\hline & Food & Ubi tumbuk & $\begin{array}{l}8 \text { months old, having } \\
\text { buds }\end{array}$ & $\begin{array}{l}\text { The flowers were sliced into small pieces and mixed into } u b i \\
\text { tumbuk }\end{array}$ \\
\hline & & Ikan arsik & $\begin{array}{l}8 \text { months old having } \\
\text { buds }\end{array}$ & $\begin{array}{l}\text { The flowers were sliced into small pieces and mixed into ikan } \\
\text { arsik. }\end{array}$ \\
\hline & & Sambal kincung & $\begin{array}{l}\text { The 1-year-old, having } \\
\text { buds }\end{array}$ & The flowers were milled and mixed with sambal kincung. \\
\hline & & Getah tasak telu & 4 months old, blooming & $\begin{array}{l}\text { The flowers were sliced into small pieces and mixed into getah } \\
\text { tasak telu. }\end{array}$ \\
\hline \multirow[t]{2}{*}{ Seed } & Food & Gulen manuk & 1-year-old and brown & The seeds were finely ground and mixed into manuk gulen. \\
\hline & & Getah tasak telu & 8 months old and brown & The seeds were finely ground and mixed into getah tasak telu. \\
\hline Leaf & Medicine & Wound & Young & The leaves were pounded coarsely and taped to the wound \\
\hline
\end{tabular}

Table 3. Several studies on the bioactivity of kecombrang plants

\begin{tabular}{|c|c|c|}
\hline $\begin{array}{c}\text { Parts of } \\
\text { kecombrang }\end{array}$ & Bioactivity & Reference \\
\hline Whole plant & $\begin{array}{l}\text { Antioxidants }(\mathrm{IC} 50=995.1 \mu \mathrm{g} / \mathrm{mL} \text { ) and antibacterial (MIC values for Methicillin-resistant } \\
\text { Staphylococcus aureus }(\mathrm{MRSA})=10 \mathrm{mg} / \mathrm{mL} \text { ) }\end{array}$ & Abdelwahab et al. (2010) \\
\hline Whole plant & Antiproliperative (IC50 $=170 \pm 0.05 \mu \mathrm{g} / \mathrm{mL}$ inhibits $\mathrm{CHO}$ cell proliferation) & Mai et al. (2009) \\
\hline Flower & $\begin{array}{l}\text { Antioxidants (IC50 }=34.5 \mu \mathrm{g} / \mathrm{mL}) \text {, anticancer }(\mathrm{IC} 50=173.1 \text { and } 196.2 \mu \mathrm{g} / \mathrm{mL} \text { in } \\
\text { kelombrang flower extract of Kelantan inhibited the growth of MCF- } 7 \text { and MDA-MB-231) } \\
\text { and antibacterial cells in Kelantan flower extract (MIC Value; Staphylococcus aureus }= \\
40.0 \mu \mathrm{g} / \mathrm{mL}, \text { Bacillus subtilis }=80.0 \mu \mathrm{g} / \mathrm{mL} \text {, Listeria monocytogenes }=40.0 \mu \mathrm{g} / \mathrm{mL} \text {, } \\
\text { Escherichia coli }=>10.0 \mu \mathrm{g} / \mathrm{mL}, \text { Salmonella typhimurium }=50.0 \mu \mathrm{g} / \mathrm{mL} \text {, and } \\
\text { Pseudomonas aeruginosa }=60.0 \mu \mathrm{g} / \mathrm{mL} \text { ) }\end{array}$ & $\begin{array}{l}\text { Ghasemzadeh et al. } \\
\text { (2015) }\end{array}$ \\
\hline Flower & Total antioxidant serum $( \pm 5 \mu \mathrm{mol} / \mathrm{mg}$ protein $)$ & Jackie et al. (2011) \\
\hline Flower & $\begin{array}{l}\text { Antimicrobial (Bacillus subtilis with MIC value }=0.78 \mathrm{mg} / \mathrm{ml} \text { and Klebsiella pneumoniae } \\
\text { with MIC value }=1.56 \mathrm{mg} / \mathrm{ml} \text { ) }\end{array}$ & Wijekoon et al. (2013) \\
\hline Flower & $\begin{array}{l}\text { Antimicrobials (MIC values in various microbes ranging from } 1.563-50,000 \mathrm{mg} / \mathrm{mL} \text { ) and } \\
\text { antioxidants (IC50 }=2.52 \mathrm{mg} / \mathrm{mL} \text { ) }\end{array}$ & $\begin{array}{l}\text { Lachumy et al. (2010) } \\
\text { Maser et al. (2017) }\end{array}$ \\
\hline Flower & $\begin{array}{l}\text { Antibacteria (Staphylococcus aureus with } \mathrm{DIZ}= \pm 3,78 \mathrm{~mm} \text { in } 500 \mathrm{mg} / \mathrm{mL} \text { chloroform } \\
\text { fraction) }\end{array}$ & \\
\hline
\end{tabular}


In conclusion, kecombrang has many benefits, both as food and medicine, so agroforestry systems with kecombrang should be developed to improve the economic benefits for the community.

\section{ACKNOWLEDGEMENTS}

The authors would like to thanks the local people of the Kabanjahe subdistrict. The study was supported by the Lembaga Penelitian Universitas Sumatera Utara TALENTA USU No: 2590/UN5.1.R/PPM/2018.

\section{REFERENCES}

Abdelwahab SI, Zaman FQ, Mariod AA, Yaacob M, Abdelmageed AHA Khamis S. 2010. Chemical composition, antioxidant and antibacterial properties of the essential oils of Etlingera elatior and Cinnamomum pubescens Kochummen. J Sci Food Agric 90: 2682-2668.

Akinyode BF, Khan TH. 2018. Step by step approach for qualitative data analysis. Intl J Built Environ Sustain 5 (3): 163-174.

Assunção J, Mobarak AM, Lipscomb M, Szerman D. 2016. Agricultural productivity and deforestation in Brazil. Working Paper. INPUT, Climate Policy Initiative. Mimeo, Yale University, New Heaven, CN.

Attride-Stirling, J. 2001. Thematic networks: an analytic tool for qualitative research. Qualitative Res 1 (3): 385-405.

Bandara T, Uluwaduge I, Jansz ER. 2011. Bioactivity of cinnamon with special emphasis on diabetes mellitus: A review. Intl J Food Sci Nutr 63 (3): 380-386.

Braun V, Clarke V. 2006. Using thematic analysis in psychology. Qualitative Res Psychol 3 (2): 77-101.

BPS [Badan Pusat Penelitian]. 2017. Kecamatan Kabanjahe dalam Angka 2017. Badan Pusat Statistik Kabupaten Karo, Karo. [Indonesian]

Chan EWC, Limb YY, Wong SK. 2013. Botany, uses, phytochemistry and pharmacology of selected Etlingera gingers: A review. Pharmacogn Commun 3 (4): 1-10.

Chan EWC, Limb YY, Wong SK. 2011. Phytochemistry and Pharmacological Properties of Etlingera elatior: A Review. Pharmacogn J 3 (22): 6-10.

Delta AM, Ardinis A, Syamsuardi. 2013. Studi Jenis-Jenis Zingiberaceae di Kawasan Hutan Lindung Gunung Talang Sumatera Barat. J Bio UA 2 (3): 161-168. [Indonesian]

Fujioka K, Shibamoto T. 2008. Chlorogenic acid and caffeine contents in various commercial brewed coffees. Food Chem 106: 217-221.

Ghasemzadeh A, Jaafar HZE, Rahmat A, Ashkani S. 2015. Secondary metabolites constituents and antioxidant, anticancer and antibacterial activities of Etlingera elatior (Jack) R.M.Sm grown in different locations of Malaysia. BMC Compl Altern Med 15: 335-344.

Guimbo ID, Muller J, Larwanou M. 2011. Ethnobotanical knowledge of men, women and children in rural niger: a mixed methods approach. Ethnobot Res Appl 9: 235-242.
Hillbrand A, Borelli S, Conigliaro M, Olivier A. 2017. Agroforestry for landscape restoration. Exploring the potential of agroforestry to enhance the sustainability and resilience of degraded landscapes. Food and Agriculture Organization of the United Nations, Rome.

Himshikha. 2016. Existing agroforestry practices in Haridwar, India. Intl J Sci Res 5 (9): 993-998.

Jaafar FM, Osman CP, Ismail NH, Awang K. 2007. Analysis of essential oils of leaves, stems, flowers and rhizomes of Etlingera elatior (Jack) RM Smith. Malaysian J Anal Sci. 11 (1): 269-273.

Jackie T, Haleagrahara N, Chakravarthi S. 2011. Antioxidant effects of Etlingera elatior flower extract against lead acetate-induced perturbations in free radical scavenging enzymes and lipid peroxidation in rats. BMC Res Notes 4: 67. DOI: 10.1186/1756-05004-67.

Khaw SH. 2001. The genus Etlingera (Zingiberaceae) in Peninsular Malaysia including a new species. Gard Bull Sing 53: 191-239.

Lachumy SJT, S Sasidharan, V Sumathy, Z Zuraini. 2010. Pharmacological Activity, Phytochemical Analysis and Toxicity of Methanol Extract of Etlingera elatior (Torch Ginger) Flowers. Asian Pac J Trop Med 3 (10): 769-774.

Larsen K, Ibrahim H, Khaw SH, Saw LG. 1999. Gingers of Peninsular Malaysia and Singapore. Natural History Publications (Borneo), Kota Kinabalu.

Mai CW, Wong SY, Tan EL, Balijepalli MK, Pichika MR. 2009. Antiproliferative and apoptotic studies of the standardized extracts of Etlingera elatior on Human Colorectal Carcinoma Cells. Malaysian J Chem 11 (1): 136-142.

Maimulyanti A, Prihadi AR. 2015. Chemical composition, phytochemical and antioxidant activity from extract of Etlingera elatior flower from Indonesia. J Pharmacogn Phytochem 3 (6): 233-238.

Maser WH, Rusmarilin H, Yuliana ND. 2017. Aplikasi metabolomik berbasis HPLC untuk mengidentifikasi waktu retensi komponen antibakteri Stapylococcus aureus pada ekstrak bunga kecombrang (Etlingera elatior). Alchemy Jurnal Penelitian Kimia 13 (2): 241-251. [Indonesian]

Ruijter J, Agus F. 2004. Sistem Agroforestri. World Agroforestry Center. http: //www.worldagroforestry.org.

Sabilu Y, Sahidin, Mukaddin A, Bittikaka Y, Tawa RA, Paddo J, Saptaputra SK. 2017. The Utilization of Sikala (Etlingera elatior) as Traditional Medicine in Porehu District, North Kolaka Regency, Southeast Sulawesi Province, Indonesia. Adv Environ Biol 11 (9): 59.

Tongco MDC. 2007. Purposive Sampling as a Tool for Informant Selection. Ethnobot Res Appl 5:147-158.

Voeks RA. 2007. Are women reservoir of traditional plant knowledge? gender, ethnobotany and globalization in North Brazil. Singapore J Trop Geogr 28: 7-20.

Wijekoon JO, Karim MM, Bhat R. 2011. Evaluation of nutritional quality of Torch ginger (Etlingera elatior Jack) inflorescence. Intl Food Res J 18 (4): 1415-1420.

Wijekoon MMJO, Bhat R, Karim AA, Fazilah A. 2013. Chemical composition and antimicrobial activity of essential oil and solvent extracts of torch ginger inflorescence (Etlingera elatior Jack.). Intl J Food Prop 16: 1200-1210.

Yeats H. 2015. The history and cultivation of Etlingera the torch gingers at the Royal Botanic Garden Edinburgh. J Bot Gard Hortic 11: 71-85. 